\title{
Sputtered Tungsten Oxide as Hole Contact for Silicon Heterojunction Solar Cells
}

\author{
Mathias Mews, Antoine Lemaire and Lars Korte
}

\begin{abstract}
Reactively sputtered tungsten oxide $\left(\mathrm{WO}_{x}\right)$ was investigated as hole contact on n-type crystalline silicon. Varying the oxygen gas flow during sputtering enables variation of the WO $_{x}$ conductivity from 0.01 to $1000 \Omega / \mathrm{cm}$, while the band bending at the interface and the implied fill factor (FF) change by $70 \mathrm{meV}$ and $1.5 \%$. Sputtered WO $\mathrm{WO}_{x}$ shows higher resistivity and higher absorption in the visible range compared to ITO. Therefore stacks of $\mathrm{WO}_{x}$ and ITO are used in solar cells. It was found that at least $20 \mathrm{~nm}$ thick $W_{x}$ is needed to prevent detrimental effects of the ITO work function on the band bending at the junction, the implied FF and real FF of solar cells. WO $_{x}$ hole contacts of different thicknesses and conductivity were applied in solar cells and it was found that the highest FF is achieved using about $20 \mathrm{~nm}$ thick interlayers of $\mathbf{W O}_{x}$ with the highest possible conductivity. It was found that sputtering enables a drastic improvement of $\mathrm{WO}_{x} /$ silicon solar cells compared to thermal evaporation, due to the precise control of the $\mathrm{WO}_{x}$ conductivity. Unfortunately the resistivity of sputtered $\mathrm{WO}_{x}$ is still limiting the FF of these devices.
\end{abstract}

Index Terms-tungsten oxide, silicon heterojunction, solar cells, work function, selective contact

All authors were with the Institute of Silicon Photovoltaics of the Helmholtz-Zentrum Berlin, Kekulestrae 5, D12489 Berlin, Germany. Manuscript published in IEEE Journal of Photovoltaics http://ieeexplore.ieee.org/document/7962277/ doi:10.1109/JPHOTOV.2017.2714193

\section{INTRODUCTION}

A MORPHOUS silicon (a-Si:H) contact and passivation layers are one prominent example of heterojunction contacts for crystalline silicon (c-Si) absorbers [1], [2]. They show very high efficiency potential with record efficiencies of about $25 \%$ for both side contacted [3] and back-contact backjunction solar cells [4]. Recently the investigation of different dopant-free contact materials for $\mathrm{c}-\mathrm{Si}$ absorbers has spread to a wide range of different materials [5] including molecular organic semiconductors [6], alkali-metal salts [7] and metal oxides [8], [9].

Among those materials metal oxide contact layers have shown the most promise with more than $22 \%$ efficiency and the best stability [10].

The electron affinity of silicon is about $4.1 \mathrm{eV}$ for crystalline material and $3.8 \mathrm{eV}$ for amorphous material. Therefore electron contact layers should feature work functions below these values. For hole contacts the ionization energy is the lower limit for the work function and it is in the range of $5 \mathrm{eV}$ for silicon. Therefore high work function metal oxides like molybdenum oxide [8], [9], tungsten oxide $\left(\mathrm{WO}_{x}\right)$ [11], [12] and vanadium oxide [13] are evaluated as hole contact materials for silicon. A typical band line-up for an indiumtin-oxide/ $\mathrm{WO}_{x} /(\mathrm{i}) \mathrm{a}-\mathrm{Si}: \mathrm{H} /(\mathrm{n}) \mathrm{c}-\mathrm{Si}$-hole contact stack is shown in

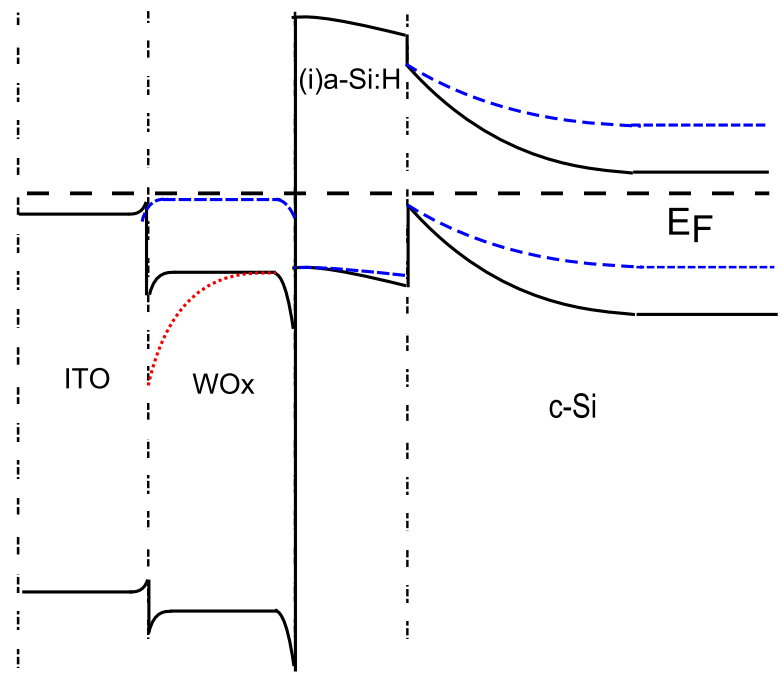

Fig. 1. Sketch of the band alignment at in an ITO/WO $/(\mathrm{i}) \mathrm{a}-\mathrm{Si}: \mathrm{H} / \mathrm{c}-\mathrm{Si}$ stack. The thick broken line marks the Fermi level. Black continuous lines are a sketch of the band alignment in a junction with a $\mathrm{WO}_{x}$ work function of about $6 \mathrm{eV}$. Broken blue lines mark the changes, for lower $\mathrm{WO}_{x}$ work functions and the red dotted line, marks the change of the band bending in $\mathrm{WO}_{x}$ for a thin $\mathrm{WO}_{x}$ layer and the band bending induced by ITO in $\mathrm{WO}_{x}$ is greatly increased. In this case the band bending in the $\mathrm{c}-\mathrm{Si}$, is best described by the broken blue line.

Figure 1. The band positions and band bendings are based on ellipsometry and He-I ultraviolet photoelectron spectroscopy measurements conducted during this study and a previous study on thermally evaporated tungsten oxide [14]. The black lines show the alignment for a $\mathrm{WO}_{x}$ work function of about $6 \mathrm{eV}$. In this case the conduction band of the metal oxide forms a well-aligned tunnel-recombination contact with silicon and a significant band bending in the n-type $\mathrm{c}-\mathrm{Si}$ is reducing the electron density at the interface. If the $\mathrm{WO}_{x}$ work function is lower than the ionization energy of silicon, the band bending in $\mathrm{c}-\mathrm{Si}$ is strongly reduced and the tunnel-recombination contact is misaligned (blue broken lines).

The metal oxide showing the best solar cell efficiencies so far, is molybdenum oxide [10]. Unfortunately a not fully explained degradation mechanism leads to insufficient thermal stability of solar cells with molybdenum oxide hole contacts, which is not compatible with typical silicon solar cell processes. Additionally molybdenum oxide degrades during the sputtering of indium-tin-oxide (ITO) overlayers [15].

Vanadium oxide shows the highest open circuit voltage, if used without a passivation layer [13] and features the thinnest native oxide at the junction of silicon and the metal oxide [16]. The problem of vanadium oxide is its low band gap of about $2.1 \mathrm{eV}$ [15], leading to significant parasitic absorption. The band gaps 
of molybdenum oxide and $\mathrm{WO}_{x}$ are about 3.1 and $3.3 \mathrm{eV}$, respectively [15].

$\mathrm{WO}_{x}$ has the highest band gap of the three metal oxides [15] and is less susceptible to thermal degradation [12] and sputter damage [15] than molybdenum oxide. Disadvantageous properties of $\mathrm{WO}_{x}$ are its thicker interfacial $\mathrm{SiO}_{x}$ at the interface to silicon [16] and a comparatively high density of oxygen vacancies in the layer, which leads to reduced band bending in the $\mathrm{Si} / \mathrm{WO}_{x}$-junction [14]. For a properly working $\mathrm{WO}_{x} / \mathrm{Si}$-junction it is essential to obtain a high band bending and good interface passivation. Multiple works have demonstrated well passivated $\mathrm{WO}_{x} / \mathrm{Si}$-junctions [11], [12], [14] with open circuit voltages above $700 \mathrm{mV}$, implied fill factors above $80 \%$ and thermal stability to at least $200^{\circ} \mathrm{C}$ [12]. Unfortunately none of the finished cells featured a FF above $80 \%$. A reduced band bending at the $\mathrm{WO}_{x} /$ silicon-interface was identified as the reason of this low fill factors [14].

So far most studies used thermal evaporation for the preparation of metal oxide contact layers and sputtering has only been applied to molybdenum oxide layers [17], or in other fields of materials research [18], [19]. Unfortunately thermal evaporation does not allow for intentional modification of the oxygen vacancy density in metal oxide layers. Therefore no systematic investigation of the influence of the oxygen vacancy density in $\mathrm{WO}_{x}$ hole contacts has been presented so far. In this contribution reactive sputtering of $\mathrm{WO}_{x}$ is employed to vary the oxygen vacancy density in $\mathrm{WO}_{x}$ layers, which leads to a variation of the conductivity by four orders of magnitude. The influence of the $\mathrm{WO}_{x}$ conductivity and the band bending in the $\mathrm{WO}_{x} / \mathrm{Si}$-junction is then investigated using solar cells.

\section{EXPERIMENTAL DETAILS}

$\mathrm{WO}_{x}$ layers were prepared using reactive RF-sputtering from a $5 \mathrm{~cm}$ wide tungsten target with partial oxygen flows from 7.5 to $15 \%$ in argon. Sputtering power was $70 \mathrm{~W}$ for layers deposited on glass, or wafers with stacks of p-type and intrinsic a-Si:H and $25 \mathrm{~W}$ for wafer samples with only intrinsic a-Si:H passivation layers. We used the lower sputtering power to prevent defect creation at the interface, which would harm the selectivity of the junction. The sputtering pressure was $8 \times 10^{-3} \mathrm{mbar}$ at a total gas flow rate of $40 \mathrm{sccm}$.

$\mathrm{N}$-type $1-5 \Omega \mathrm{cm} 280 \mu \mathrm{m}$ thick c-Si wafers were used as substrates and RCA cleaned. Solar cells were built using doubleside polished and random pyramid textured wafers. Texturing was performed using the commercial product Alkatex [20]. Wafers for surface photovoltage measurements were polished on one side and only saw damage etched on the other. All coatings on these samples were applied on the polished side and had $5 \mathrm{~nm}$ (i)a-Si:H below the metal oxide layers.

Amorphous silicon layers for solar cell fabrication were deposited using plasma enhanced chemical vapor deposition. 5 and $8 \mathrm{~nm}$ thick intrinsic layers were deposited using pure silane gas with a $\mathrm{H}$ plasma after treatment [21]. $8 \mathrm{~nm}$ thick doped layers were deposited using a diborane and phosphine diluted in hydrogen as doping gases, $0.5 \mathrm{mbar}$ pressure and powers densities of $20 \mathrm{~mW} / \mathrm{cm}^{2}$. The wafers silicon oxide was stripped of by $\mathrm{HF}(1 \%, 30 \mathrm{~s}$ to 3 min depending on process step and

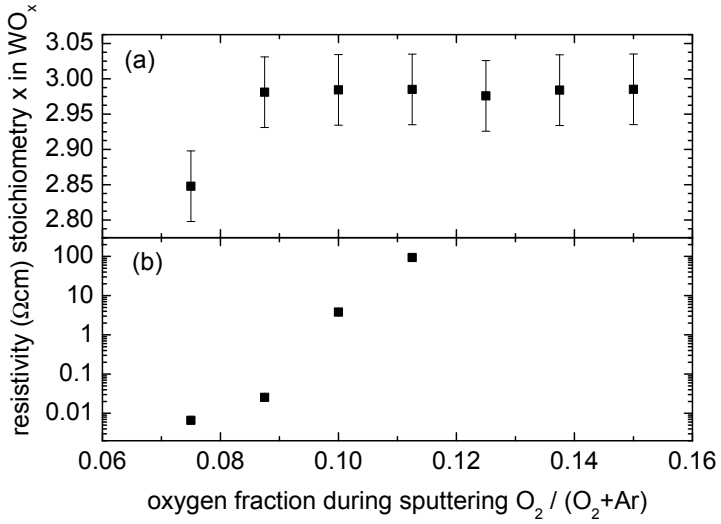

Fig. 2. (a) Stoichiometry, as calculated from XPS, and (b) resistivity of tungsten oxide $\left(\mathrm{WO}_{x}\right)$ plotted versus the partial oxygen gas flow during reactive sputtering.

sample surface).

ITO was deposited using RF-sputtering at room temperature from a ceramic target with $0.36 \%$ oxygen in argon as sputter gas and $70 \mathrm{~W}$ sputter power. Front side ITO was deposited through a mask to define the active solar cell area of $1 \mathrm{~cm}^{2}$ with 12 cells per wafer. After sputtering the samples were annealed for 5 minutes at $200^{\circ} \mathrm{C}$ to cure sputter damage. Metallization was done by thermal evaporation of $10 \mathrm{~nm}$ titanium and $1500 \mathrm{~nm}$ silver.

X-ray photoelectron spectroscopy (XPS) was conducted to evaluate the stoichiometry of the layers. An $\mathrm{Al} \mathrm{K} \mathrm{K}_{\alpha}$ source was used for excitation. The fitting model was adopted from Lee et al. [22], [23] and the samples were exposed to air, while being transported to the XPS set-up.

Optical spectroscopy of the layers was performed to calculate absorption and transmission using a Perkin Elmer Lambda 19 spectrometer. Injection level dependent carrier lifetime curves were extracted from samples using a Sinton Consulting WCT100 set-up [24] and these were used to calculate implied fill factors [25].

Surface photovoltage measurements were conducted in a home-built set-up using $905 \mathrm{~nm}$ laser excitation [26]. Solar cell measurements were conducted using a solar simulator with class AAA AM1.5GMM illumination at $25^{\circ} \mathrm{C}$.

Layer conductivities were determined using layers on corning glass and a four-point probe set-up.

\section{RESULTS AND DISCUSSION}

\section{A. Tungsten oxide layer properties}

As outlined in the introduction, the aim of this study is to investigate the influence of the conductivity, stoichiometry and optical properties of $\mathrm{WO}_{x}$ on solar cells using $\mathrm{WO}_{x}$ as a hole-selective contact on a c-Si absorber. Therefore $\mathrm{WO}_{x}$ layers prepared with different oxygen to argon gas flow ratios during sputtering were analyzed. First the stoichiometry of $50 \mathrm{~nm}$ thick $\mathrm{WO}_{x}$ layers on silicon wafers is evaluated using XPS. In Figure 2a the stoichiometry of different $\mathrm{WO}_{x}$ layers is plotted versus the oxygen flow during the sputter process. Only the layer with the lowest oxygen flow of $0.75 \%$ is not 


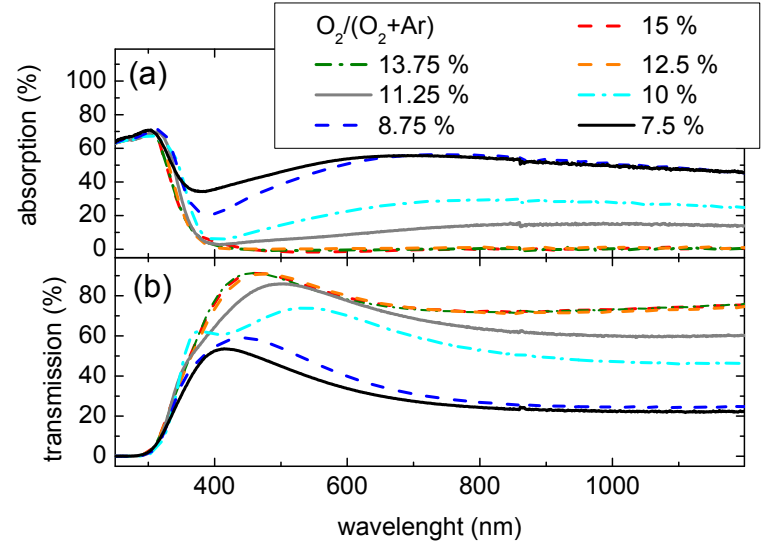

Fig. 3. (a) absorption and (b) transmission of tungsten oxide layers prepared using different partial oxygen flows during reactive sputter deposition.

fully stoichiometric $\mathrm{WO}_{3}$.

Secondly the conductivity of $\mathrm{WO}_{x}$ has been measured for the same parameter sets using $100 \mathrm{~nm}$ thick layers on glass. Figure $2 \mathrm{~b}$ displays these values. The layer's conductivity changes by at least four orders of magnitude in the investigated oxygen flow range. For the 3 highest oxygen flows it is actually below the measurable range of our four-point probe set-up. The lowest resistivity is measured for the slightly substoichiometric layer and is about $0.007 \Omega \mathrm{cm}$. This is still below the conductivity of typical ITO layers, which is the transparent conductive oxide commonly used in silicon heterojunction solar cells.

Figure 3 shows the absorption (a) and transmission (b) of the same $\mathrm{WO}_{x}$ layers. It is obvious that increased conductivity of $\mathrm{WO}_{x}$ leads to increased absorption in the full wavelength range from 400 to $1200 \mathrm{~nm}$. This is related to a general darkening of the films by an increased amount of oxygen vacancies. The increase of oxygen vacancies leads to a metal like conductivity with the corresponding increase in light absorption. Additionally an increase of free carriers absorption is likely, but less obvious. Overall no suitable range of low absorption and high conductivity can be found for $\mathrm{WO}_{x}$. Therefore $\mathrm{WO}_{x}$ cannot replace typical transparent conductive oxides like ITO [27]. On the other hand these $\mathrm{WO}_{x}$ layers are more conductive and more transparent than typical p-doped amorphous silicon hole contact layers [27], which makes it a candidate for their replacement.

\section{B. Band bending and implied fill factor of $\mathrm{WO}_{x}$ on n-type crystalline silicon}

A good minority carrier contact, in this case a hole contact, needs to induce a sufficient band bending in the absorber, to reduce the density of the majority carrier type at the interface (see Figure 1). Additionally it needs to provide sufficient passivation. Surface photovoltage measurements were conducted to investigate the band bending of $\mathrm{WO}_{x} /(\mathrm{i}) \mathrm{a}-\mathrm{Si}: \mathrm{H}$ stacks with different $\mathrm{WO}_{x}$ thicknesses and $\mathrm{WO}_{x}$ sputtered at different oxygen flow rates. Additionally photoconductance decay measurements were conducted to investigate the implied fill factor of $\mathrm{WO}_{x} /(\mathrm{i}) \mathrm{a}-\mathrm{Si}: \mathrm{H}$ hole contacts on planar

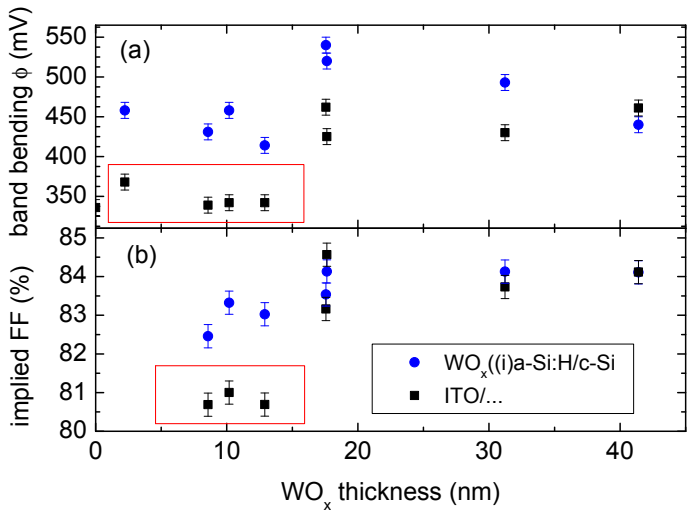

Fig. 4. (a) band bending in $\mathrm{WO}_{x} /(\mathrm{i}) \mathrm{a}-\mathrm{Si}: \mathrm{H} /(\mathrm{n}) \mathrm{c}-\mathrm{Si}$ stacks plottet versus the thickness of tungsten oxide (blue circles) and band bending in the same samples after the deposition of ITO on the tungsten oxide (black squares). (b) Implied fill factor from photoconductive decay measurements of $\mathrm{WO}_{x} /(\mathrm{i}) \mathrm{a}$ $\mathrm{Si}: \mathrm{H} /(\mathrm{n}) \mathrm{c}-\mathrm{Si} /(\mathrm{i}) \mathrm{a}-\mathrm{Si}: \mathrm{H} /(\mathrm{n}) \mathrm{a}-\mathrm{Si}: \mathrm{H} / \mathrm{ITO}$ samples (blue circles) and of the same samples after the deposition of an additional ITO layer on the $\mathrm{WO}_{x}$ (black squares). The combined thickness of front ITO and $\mathrm{WO}_{x}$ was always about $80 \mathrm{~nm}$.

n-type c-Si.

Additionally ITO/ $/ \mathrm{WO}_{x} /(\mathrm{i}) \mathrm{a}-\mathrm{Si}$ :H-stacks are investigated, since the conductivity of $\mathrm{WO}_{x}$ is too low to replace ITO.

Figure $4 \mathrm{a}$ shows the band bending across the $\mathrm{WO}_{x} /(\mathrm{i}) \mathrm{a}$ $\mathrm{Si}: \mathrm{H} /(\mathrm{n}) \mathrm{c}-\mathrm{Si}$-junction of samples with and without ITO on top of the $\mathrm{WO}_{x}$. The $\mathrm{WO}_{x}$ in this series was sputtered at $70 \mathrm{~W}$ sputtering power and a partial oxygen flow of $12.5 \%$ oxygen in argon. The thickness of the intrinsic a-Si:H layers was $8 \mathrm{~nm}$ to prevent sputter damage at the high sputtering power. The band bending in the samples without ITO does not follow a clear trend. It scatters between 400 and $550 \mathrm{meV}$ with a possible maximum at a $\mathrm{WO}_{x}$ thickness of about $20 \mathrm{~nm}$. After the deposition of ITO onto these samples, the bend banding in all samples with less than about $18 \mathrm{~nm}$ of $\mathrm{WO}_{x}$ drops to about 300 to $350 \mathrm{meV}$. In contrast the band bending stays above $400 \mathrm{meV}$, if the $\mathrm{WO}_{x}$ thickness is above $20 \mathrm{~nm}$.

Figure $4 \mathrm{~b}$ shows the implied FF calculated from photoconductance decay measurements on $\mathrm{WO}_{x} /(\mathrm{i}) \mathrm{a}$ $\mathrm{Si}: \mathrm{H} /(\mathrm{n}) \mathrm{c}-\mathrm{Si} /(\mathrm{i}, \mathrm{n}) \mathrm{a}-\mathrm{Si}: \mathrm{H} / \mathrm{ITO}$ samples and of the same samples with an additional ITO layer on top of the $\mathrm{WO}_{x}$. The implied fill factor of samples without ITO is almost constant. After ITO deposition the implied fill factors drop similar to the band bendings for all samples with less than $18 \mathrm{~nm} \mathrm{WO}_{x}$. To sum up these findings: The high work function of $\mathrm{WO}_{x}$ is only reflected in higher band bendings and implied fill factors, if its thickness is at least $20 \mathrm{~nm}$. Otherwise the lower work function of ITO is not sufficiently screened by the too thin layer of $\mathrm{WO}_{x}$ and the band bending at the interface is decreased. This is sketched as a red dotted line in figure 1. The effect of the $\mathrm{WO}_{x}$ thickness in solar cells will be investigated later in this manuscript, but based on the data presented so far it can be expected that a layer thickness below $18 \mathrm{~nm}$ will be detrimental.

The changes in stoichiometry and conductivity of $\mathrm{WO}_{x}$ for different oxygen fractions in the sputter gas were already discussed. Figure 5 shows the influence of the oxygen 


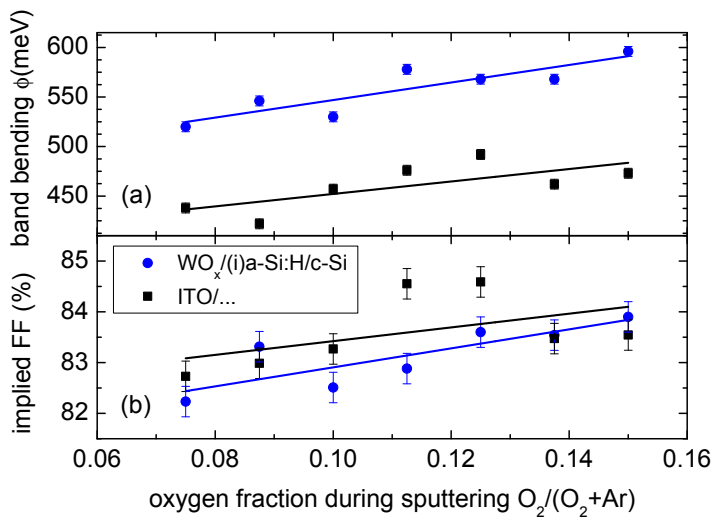

Fig. 5. (a) band bending in $\mathrm{WO}_{x} /(\mathrm{i}) \mathrm{a}-\mathrm{Si}: \mathrm{H} /(\mathrm{n}) \mathrm{c}-\mathrm{Si}$ samples plotted versus the oxygen concentration in the sputter gas during $\mathrm{WO}_{x}$ deposition. (b) implied fill factor from photoconductance decay measurements for $\mathrm{WO}_{x}(\mathrm{i}) \mathrm{a}-$ $\mathrm{Si}: \mathrm{H} /(\mathrm{n}) \mathrm{c}-\mathrm{Si} /(\mathrm{i}, \mathrm{n}) \mathrm{a}-\mathrm{Si}: \mathrm{H} / \mathrm{ITO}$ samples with $\mathrm{WO}_{x}$ prepared with different oxygen fractions in the sputtering gas. Values for samples with (black squares) and without (blue circles) ITO on the $\mathrm{WO}_{x}$ are shown in both panels.

fraction during sputtering on the band bending in the $\mathrm{WO}_{x} /(\mathrm{i}) \mathrm{a}-\mathrm{Si}: \mathrm{H} /(\mathrm{n}) \mathrm{c}-\mathrm{Si}$-junction (panel a) and the implied FF of solar cell precursors with $\mathrm{WO}_{x}$ hole contact layers (panel b). These $\mathrm{WO}_{x}$ layers were about 20 to $30 \mathrm{~nm}$ thick, sputtered with $25 \mathrm{~W}$ sputtering power and the sample structure was the same as in the previous data. Additionally all samples were again measured before and after the deposition of ITO on the $\mathrm{WO}_{x}$.

An increase in oxygen flow leads to an increase of the band bending before and after the deposition of ITO. A likely explanation is an increasing work function of $\mathrm{WO}_{x}$ with increasing oxygen fraction during sputtering. Earlier studies found that the work function of $\mathrm{WO}_{x}$ increases with its stoichiometry [14], which is typically correlated with an decrease of its Fermi level. This decrease in Fermi-level position leads to a decrease in conductivity. This descreasing conductivity is shown in figure 2 and is related to increasing oxygen fraction in the sputter gas and increasing oxygen fraction in the layer. Additionally the measured band bending in samples with ITO is systematically lower than in samples without ITO. This is most likely due to the lower work function of ITO, which counteracts the work function of $\mathrm{WO}_{x}$.

Higher oxygen flows during sputtering are also beneficial for the implied FF of $\mathrm{WO}_{x}$ hole contacts. The explanation is again linked to the lower Fermi-levels and higher work functions of these layers [14]. However the overall change in implied FF is only in the range of $2 \%$.

\section{SOLAR CELlS EMPLOYING TUNGSTEN OXIDE LAYERS}

Analyzing the band bending and implied FF measurements it is obvious that the oxygen flow rate during the $\mathrm{WO}_{x}$ sputtering and the thickness of the $\mathrm{WO}_{x}$ layers are important parameters for $\mathrm{WO}_{x}$ hole contacts layers in silicon heterojunction solar cells and therefore the optimization of these parameters will be discussed in the following. Figure 6 shows

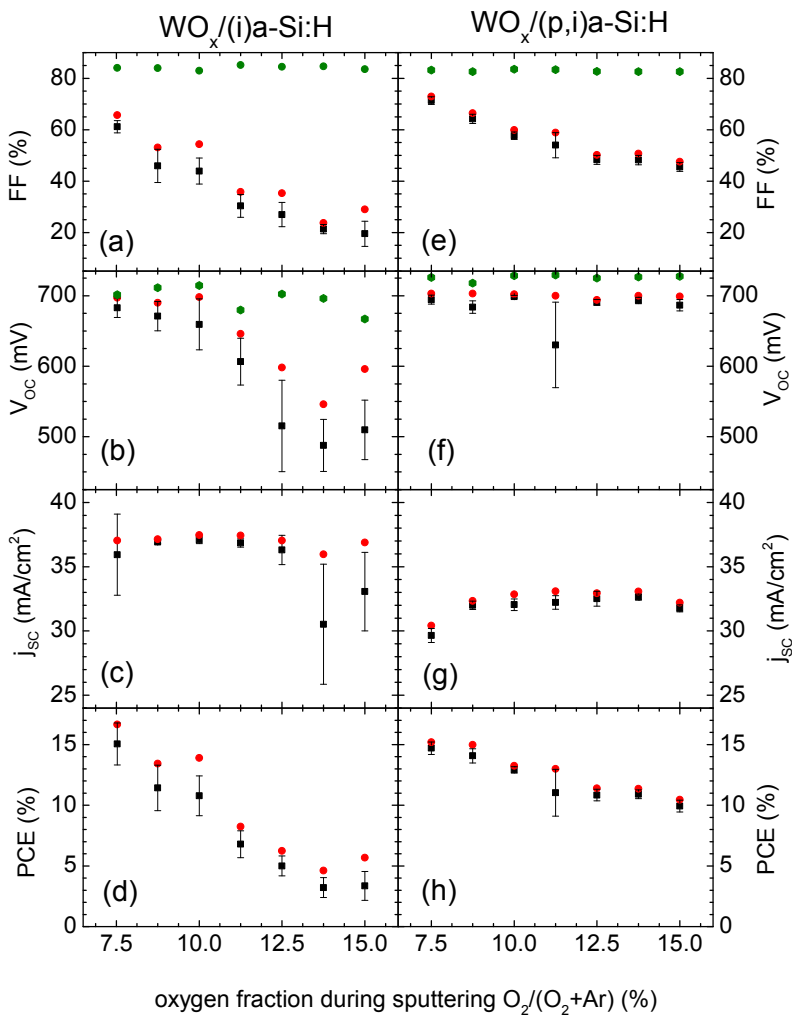

Fig. 6. Fill factor $\mathrm{FF}$ (a and e), open circuit voltage $\mathrm{V}_{\mathrm{OC}}$ (b and $\mathrm{f}$ ), short circuit current density jSC $_{\mathrm{SC}}(\mathrm{c}$ and $\mathrm{g}$ ) and photovoltaic conversion efficiency PCE ( $\mathrm{d}$ and $\mathrm{h}$ ) of solar cells with $\mathrm{WO}_{x}$ hole contact layers. The figure shows two groups of solar cells. The partial oxygen flow during the sputtering process was varied from 7.5 to 15 for both cell groups. The first cell group (panels a,b,c,d) uses $\mathrm{WO}_{x}$ as hole contact layer and has the structure ITO/WO ${ }_{x} /(\mathrm{i}) \mathrm{a}-\mathrm{Si}: \mathrm{H} /(\mathrm{n}) \mathrm{c}-\mathrm{Si} /(\mathrm{i}, \mathrm{n}) \mathrm{a}-\mathrm{Si}: \mathrm{H} / \mathrm{ITO}$ and was fabricated on textured wafers. The second cell group (e,f,g,h) uses a bilayer hole contact consisting of $\mathrm{WO}_{x}$ and p-type a-Si:H and has the structure $\mathrm{ITO} / \mathrm{WO}_{x} /(\mathrm{p}, \mathrm{i}) \mathrm{a}-\mathrm{Si}: \mathrm{H} /(\mathrm{n}) \mathrm{c}-$ $\mathrm{Si} /(\mathrm{i}, \mathrm{n}) \mathrm{a}-\mathrm{Si}$ :H/ITO and was fabricated on planar wafers. Black squares with ranges mark average values with the standard deviation of the 12 solar cells on the respective wafers. Red squares mark the maximum value of each wafer and green circles mark the implied $\mathrm{FF}$ and implied $\mathrm{V}_{O C}$ values from photoconductance decay measurements after ITO sputtering and annealing.

cell results for solar cells which include $\mathrm{WO}_{x}$ layers in their front-side hole contacts. The first group (left column) uses only $\mathrm{WO}_{x}$ as hole contact layer and has a structure of ITO/ $\mathrm{WO}_{x} /(\mathrm{i}) \mathrm{a}-\mathrm{Si}: \mathrm{H} /(\mathrm{n}) \mathrm{c}-\mathrm{Si} /(\mathrm{i}, \mathrm{n}) \mathrm{a}-\mathrm{Si}: \mathrm{H} / \mathrm{ITO}$. The fill factor (FF), open circuit voltage $\left(\mathrm{V}_{O C}\right)$, short circuit current density $\left(\mathrm{j}_{S C}\right)$ and photovoltaic conversion efficiency (PCE) of these cells are shown in panels $\mathrm{a}, \mathrm{b}, \mathrm{c}$ and $\mathrm{d}$, respectively. The second group of cells (right column) employs $\mathrm{WO}_{x} /(\mathrm{p}) \mathrm{a}-\mathrm{Si}: \mathrm{H}$ hole contacts. In these cells $\mathrm{WO}_{x}$ is only used as an interlayer to adjust the work function at the ITO/(p)a-Si:H interface and the band bending is provided by the (p)a-Si:H. The structure of those cells is ITO/WO $/(\mathrm{p}, \mathrm{i}) \mathrm{a}-\mathrm{Si}: \mathrm{H} /(\mathrm{n}) \mathrm{c}-\mathrm{Si} /(\mathrm{i}, \mathrm{n}) \mathrm{a}-\mathrm{Si}: \mathrm{H} / \mathrm{ITO}$ and their FF, $\mathrm{V}_{O C}, \mathrm{j}_{S C}$ and PCE are displayed in panels e, f, $\mathrm{g}$ and $\mathrm{h}$, respectively. Additionally the implied FF and implied $\mathrm{V}_{O C}$ from photoconductance decay measurements are shown in the respective panels as green circles for both cell groups. The $\mathrm{WO}_{x}$ in these solar cells is about 20 to $25 \mathrm{~nm}$ thick for planar wafers and 25 to $30 \mathrm{~nm}$ for textured wafers.

Now we discuss the influence of the oxygen fraction in the 


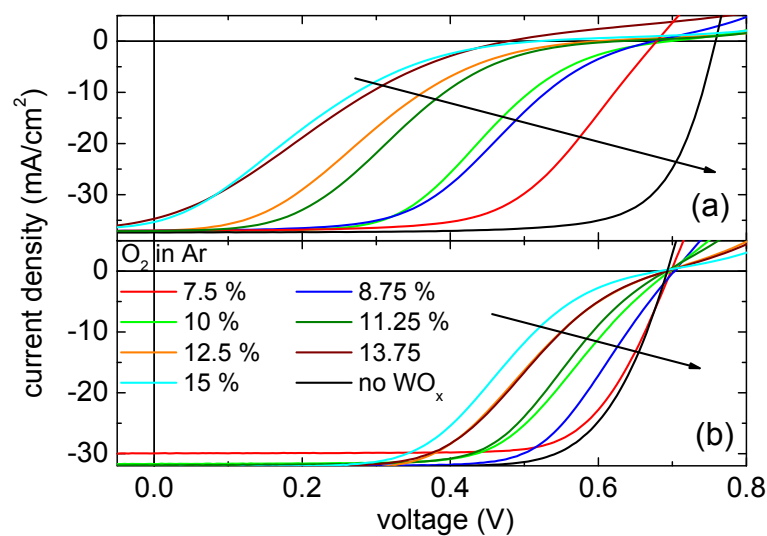

Fig. 7. j(U)-curves of (a) ITO/WO $\mathrm{WO}_{x} /(\mathrm{i}) \mathrm{a}-\mathrm{Si}: \mathrm{H} /(\mathrm{n}) \mathrm{c}-\mathrm{Si} /(\mathrm{i}, \mathrm{n}) \mathrm{a}-\mathrm{Si}: \mathrm{H} / \mathrm{ITO}$ and (b) ITO/ $\mathrm{WO}_{x} /(\mathrm{p}, \mathrm{i}) \mathrm{a}-\mathrm{Si}: \mathrm{H} /(\mathrm{n}) \mathrm{c}-\mathrm{Si} /(\mathrm{i}, \mathrm{n}) \mathrm{a}-\mathrm{Si}: \mathrm{H} / \mathrm{ITO}$ with different oxygen gas flows during the tungsten oxide sputtering. The arrows are guides to the eye and mark decreasing oxygen gas flows.

sputter gas on solar cells. In the last two sections it was shown that the oxygen flow mainly changes the conductivity of the $\mathrm{WO}_{x}$ and the band bending in the $\mathrm{WO}_{x} / \mathrm{Si}$-junction. The two different cell groups make it possible to discriminate between the influence of the changing band bending and the changing conductivity, since the band bending is dependent on the $\mathrm{WO}_{x}$ only for the first group of cells, whereas the band bending in the cells with a (p)a-Si:H contact is defined by the doping of the (p)a-Si:H and only the $\mathrm{WO}_{x}$ conductivity has an influence. Investigating the cell data in figure 6 it is obvious that increasing oxygen gas flow during the $\mathrm{WO}_{x}$ deposition leads to decreasing FFs (panels a and e). This can be explained by an increase in series resistance of the $\mathrm{WO}_{x}$. Although the invers behavior would be expected if the work function of $\mathrm{WO}_{x}$ and interface band bending were the dominant contact properties. Additionally the decrease in FF is stronger for the cells without (p)a-Si:H. The cells with a $\mathrm{WO}_{x}$ hole contact layer show a maximum FF of $60 \%$ and decrease to about $20 \%$ for the highest oxygen flows. The effect is less pronounced for the cells with a $\mathrm{WO}_{x} /(\mathrm{p}) \mathrm{a}-\mathrm{Si}: \mathrm{H}$ hole contact, where the $\mathrm{FF}$ decreases from about $71 \%$ to about $48 \%$. This shows that the decreasing conductivity of $\mathrm{WO}_{x}$ reduces the $\mathrm{FF}$ and judging from the $\mathrm{j}(\mathrm{V})$-curves of the same devices shown in Figure $7 \mathrm{a}$ cells with $\mathrm{WO}_{x}$ layers sputtered at high oxygen flow rates also show poor selectivity, since the $\mathrm{j}(\mathrm{V})$-curves are developing sshapes with increasing oxygen flow during sputtering. Overall no cell in these two groups reaches their implied FF's of about $83 \%$. Additionally the ITO/(p,i)a-Si:H reference solar cells of both series show only fill factors of about $72 \%$, which is due to too thin metal grid lines.

Figure $7 \mathrm{~b}$ shows the $\mathrm{j}(\mathrm{V})$-curves of the solar cells with a ITO/WO ${ }_{x} /(\mathrm{p}, \mathrm{i}) \mathrm{a}-\mathrm{Si}: \mathrm{H} /(\mathrm{n}) \mathrm{c}-\mathrm{Si} /(\mathrm{i}, \mathrm{n}) \mathrm{a}-\mathrm{Si}$ :H/ITO structure. The decreasing FF with increasing oxygen flow during sputtering is visible and leads to an s-shaped $\mathrm{j}(\mathrm{V})$-curve, but far less pronounced than for the ITO/ $\mathrm{WO}_{x} /(\mathrm{i}) \mathrm{a}-\mathrm{Si}: \mathrm{H} /(\mathrm{n}) \mathrm{c}-\mathrm{Si} /(\mathrm{i}, \mathrm{n}) \mathrm{a}-$ $\mathrm{Si}: \mathrm{H} / \mathrm{ITO}$ structure.

The open circuit voltage of the solar cells is plotted in Figure $6 \mathrm{~b}$ and e. The solar cells with a $\mathrm{WO}_{x} /(\mathrm{p}) \mathrm{a}-\mathrm{Si}: \mathrm{H}$ hole contact show stable $\mathrm{V}_{O C}$ and implied $\mathrm{V}_{O C}$. Note that the band bending in this contact is also stable irrespective of the used $\mathrm{WO}_{x}$, since the p-doped a-Si:H defines the junctions band bending. In contrast the solar cells with $\mathrm{WO}_{x}$ hole contact layers show more varying implied $\mathrm{V}_{O C}$ and decreasing $\mathrm{V}_{O C}$ values, for increasing oxygen flow rate. The decreasing $\mathrm{V}_{O C}$ for $\mathrm{WO}_{x} /(\mathrm{i}) \mathrm{a}-\mathrm{Si}: \mathrm{H}$ contacts with $\mathrm{WO}_{x}$ sputtered at high oxygen flows points towards selectivity issues at these interfaces. Although these contacts feature the higher band bendings, as is visible in figure 5 and was confirmed by SPV measurements of these solar cells.

Figure 6c and $\mathrm{g}$ show the short circuit current densities of the solar cells. Although the transparency of the $\mathrm{WO}_{x}$ layers decreases with decreasing oxygen flow during sputtering, this trend is not reflected in reducing $\mathrm{j}_{S C}$ values. The most likely explanation is that the variation in $\mathrm{j}_{S C}$ is negligible compared to variations due to changes in texture (panel c) and thickness of the anti-reflection layers of the planar cells (panel g). The combined ITO/ $\mathrm{WO}_{x}$ front side layer was used as antireflection layer, and due to variations of the sputtering rate with oxygen flow leading to variations in the anti-reflection properties. Overall there is no visible trend in the solar cells $\mathrm{j}_{S C}$.

The PCE of the solar cells is plotted in Figure $6 \mathrm{~d}$ and h. It mostly follows the trend of the FF discussed earlier.

Overall this series shows that the oxygen partial flow during sputtering, which was shown to influence the $\mathrm{WO}_{x}$ conductivity, significantly impacts the performance of $\mathrm{WO}_{x}$ hole contacts on silicon.

The second $\mathrm{WO}_{x}$ layer property, which was varied in solar cells is the thickness of the $\mathrm{WO}_{x}$. Planar wafers were selected for this experiment to enable direct control of the deposited thicknesses. The thickness of the overlying ITO was adjusted to maintain a total metal oxide thickness of 80 to $85 \mathrm{~nm}$ on planar surfaces.

Samples with $\mathrm{WO}_{x}$ thicknesses from 0 to $40 \mathrm{~nm}$ were prepared using a partial oxygen flow of $8.75 \%$. In Figure $8 \mathrm{a}$ it can be seen that $20 \mathrm{~nm}$ of $\mathrm{WO}_{x}$ yields the maximum FF. For higher $\mathrm{WO}_{x}$ thicknesses the FF is decreasing because of the high series resistance of the $\mathrm{WO}_{x}$ layers. For thicknesses below $20 \mathrm{~nm}$ the FF is lower, because the low ITO work function is projected through the $\mathrm{WO}_{x}$ and onto the interface to (p)a-Si:H. This corresponds to the surface photovoltage and implied FF results presented in figure 4 and to the red dotted line sketched in figure 1. Unfortunately the $\mathrm{WO}_{x}$ solar cells show lower FFs than the reference solar cells without $\mathrm{WO}_{x}$, which reveals that the high resistivity of $\mathrm{WO}_{x}$ is limiting these solar cells.

Figure $8 \mathrm{~b}$ displays the $\mathrm{V}_{\mathrm{OC}}$ of these solar cells. It is obvious that the $\mathrm{WO}_{x}$ interlayer is not influencing the $\mathrm{V}_{\mathrm{OC}}$ of the cells, as all solar cells including the reference have comparable $\mathrm{V}_{\mathrm{OC}}$. The most likely reason is that, the $\mathrm{V}_{\mathrm{OC}}$ is determined by the band bending induced by the (p)a-Si:H hole contact.

The short circuit current density is plotted versus the $\mathrm{WO}_{x}$ film thickness in Figure 8c. The short circuit current density is decreasing with increasing $\mathrm{WO}_{x}$ thickness. This is mostly because $\mathrm{WO}_{x}$ sputtered at $8.75 \%$ partial oxygen flow has a higher parasitic absorption than ITO.

Finally the PCE is plotted in Figure 8d. Comparing the reference solar cell and the $\mathrm{WO}_{x}$ solar cells, it is obvious that 


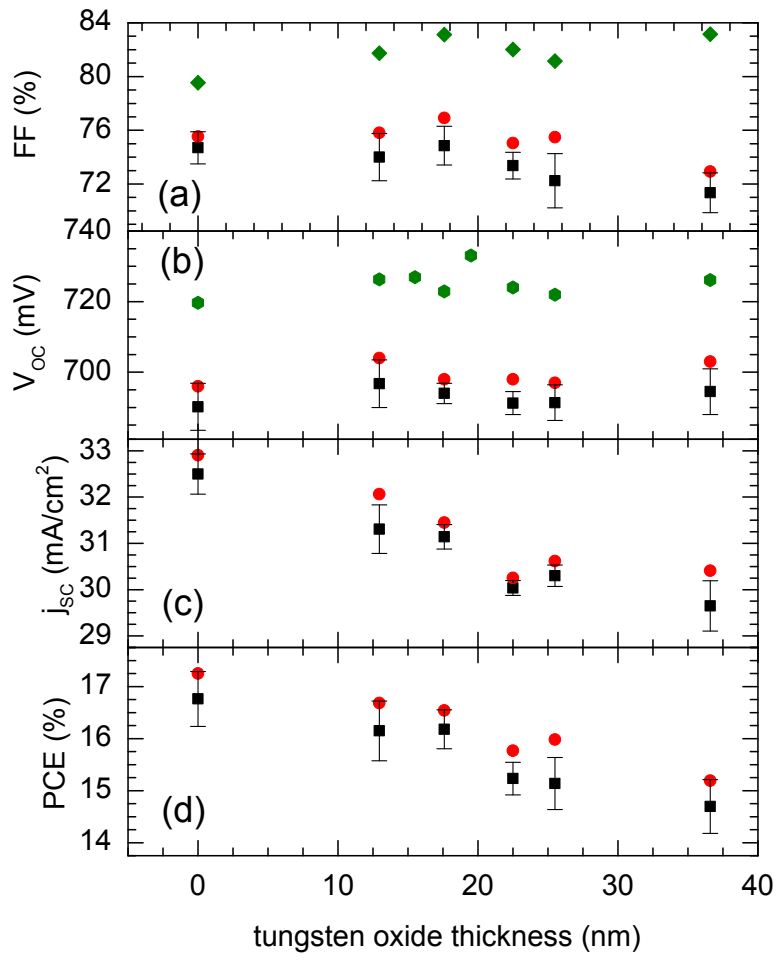

Fig. 8. Fill factor $\mathrm{FF}$ (a), open circuit voltage $\mathrm{V}_{\mathrm{OC}}$ (b), short circuit current density $\mathrm{j}_{S C}$ (c) and photovoltaic conversion efficiency PCE (d) of solar cells with $\mathrm{WO}_{x}$ hole contact layers plotted versus the $\mathrm{WO}_{x}$ thickness. The cells were fabricated on planar (100) wafers and have the structure ITO/ $\mathrm{WO}_{x} /(\mathrm{p}, \mathrm{i}) \mathrm{a}-$ $\mathrm{Si}: \mathrm{H} /(\mathrm{n}) \mathrm{c}-\mathrm{Si} /(\mathrm{i}, \mathrm{n}) \mathrm{a}-\mathrm{Si}: \mathrm{H} / \mathrm{ITO}$. Black squares with ranges mark average values with the standard deviation of the 12 cells on each respective wafer. Red squares mark the maximum value of each wafer and green squares mark the implied $\mathrm{FF}$ and implied $\mathrm{V}_{\mathrm{OC}}$ from photoconductance decay measurements after ITO sputtering and annealing.

the low conductivity of $\mathrm{WO}_{x}$ prevents a positive impact of its increased work function. Therefore future studies on improving the conductivity of $\mathrm{WO}_{x}$ layers are needed. Additionally the fill factors of both the reference and the $\mathrm{WO}_{x}$ solar cells are unfortunately limited by the series resistance of the metal grid.

\section{CONCLUSION}

Following the conclusions of earlier studies, which found that thermal evaporation is not able to offer a sufficient control of the oxygen vacancy density in $\mathrm{WO}_{x}$, sputtered $\mathrm{WO}_{x}$ was investigated as hole contact and interlayer in silicon heterojunction solar cells. Reactive sputtering was applied to adjust the stoichiometry and oxygen vacancy density of $\mathrm{WO}_{x}$. This enabled to adjust the conductivity of $\mathrm{WO}_{x}$ over three orders of magnitude and also to tune its parasitic absorption in the visible range. The improved reproducibility and ease of layer modification by sputtering parameter changes render reactively sputtered $\mathrm{WO}_{x}$ layers more suitable for the further development of metal oxide contacts for solar cells than layers prepared by thermal evaporation.

Unfortunately the conductivity of these sputtered and undoped $\mathrm{WO}_{x}$ is about one order of magnitude below that of typical transparent conductive oxides, while the parasitic absorption in this $\mathrm{WO}_{x}$ is higher than in e.g. ITO. Therefore $\mathrm{WO}_{x}$ was applied in stacks with ITO in this study.

It was found that a low $\mathrm{WO}_{x}$ conductivity is beneficial for the band bending in the $\mathrm{WO}_{x} / \mathrm{Si}$-junction. Investigating stacks of $\mathrm{WO}_{x}$ and ITO it was found that about 16 to $18 \mathrm{~nm}$ of $\mathrm{WO}_{x}$ are necessary to benefit from $\mathrm{WO}_{x}$ higher work function and prevent a detrimental influence of the lower ITO work function onto the interface between $\mathrm{WO}_{x}$ and silicon. The best solar cell using $\mathrm{WO}_{x}$ as the hole contact and thus not having any $\mathrm{p}$ doped layer showed $16.6 \%$ efficiency. The $\mathrm{WO}_{x}$ in this solar cell was prepared using $7.5 \%$ oxygen in the sputter gas and had a resisitivity of about $0.01 \Omega / \mathrm{cm}$. Additionally using $\mathrm{WO}_{x}$ as an interlayer between p-type amorphous silicon and ITO lead only to efficiencies comparable to, but below the reference solar cells. All solar cells showed higher implied fill factors, than the corresponding cells without $\mathrm{WO}_{x}$. However it was not possible to transfer this high implied fill factor into a device. The main reason for this is the high series resistance of $\mathrm{WO}_{x}$ and an overall lower band bending for $\mathrm{WO}_{x}$ layers with higher conductivity.

In summary, it was shown that sputtering of $\mathrm{WO}_{x}$ enables decent control of its conductivity and stoichiometry, but the overall conductivity of these layers is still to low to enable highly efficient hole contacts on silicon. Therefore it is suggested that future studies should focus on increasing the conductivity of $\mathrm{WO}_{x}$, while, if possible, maintain a high work function. A possible route towards higher conductive $\mathrm{WO}_{x}$ could be extrinsic doping [28].

\section{ACKNOWLEDGMENT}

The authors would like to thank Thomas Lußky, Erhard Conrad, Kerstin Jacob and Mona Wittig for wafer cleaning and vacuum system maintenance. Financial support from by the European Commission through the Project NextBase (Grant No. 727523) is acknowledged. A.L. acknowledges support from the ERASMUS PLUS program of the French ERASMUS agency and the Languedoc Roussillon region.

\section{REFERENCES}

[1] M. Tanaka, M. Taguchi, T. Matsuyama, T. Sawada, S. Tsuda, S. Nakano, H. Hanafusa, and Y. Kuwano, "Development of New a-Si/c-Si Heterojunction Solar Cells: ACJ-HIT (Artificially Constructed JunctionHeterojunction with Intrinsic Thin-Layer)," Jpn. J. Appl. Phys., vol. 31, pp. 3518-3522, 1992.

[2] S. De Wolf, A. Descoeudres, Z. C. Holman, and C. Ballif, "Highefficiency Silicon Heterojunction Solar Cells: A Review," Green, vol. 2, pp. 7-24, 2012.

[3] D. Adachi, J. L. Hernandez, and K. Yamamoto, "Impact of carrier recombination on fill factor for large area heterojunction crystalline silicon solar cell with $25.1 \%$ efficiency," Appl. Phys. Lett., vol. 107, p. 233506, 2015.

[4] K. Yoshikawa, H. Kawasaki, W. Yoshida, T. Irie, K. Konishi, K. Nakano, T. Uto, D. Adachi, M. Kanematsu, H. Uzu, and K. Yamamoto, "Silicon heterojunction solar cell with interdigitated back contacts for a photoconversion efficiency over 26

[5] C. Battaglia, A. Cuevas, and S. D. Wolf, "High-efficiency crystalline silicon solar cells: status and perspectives," Energy Environ. Sci., vol. 9, pp. 1552-1576, 2016.

[6] D. Zielke, A. Pazidis, F. Werner, and J. Schmidt, "Organic-silicon heterojunction solar cells on n-type silicon wafers: The backpedot concept," Sol. En. Mat. Sol. Cells, vol. 131, pp. 110 - 116, 2014, sI: SiliconPV 2014. 
[7] J. Bullock, M. Hettick, J. Geissbühler, A. J. Ong, T. Allen, C. M. SutterFella, T. Chen, H. Ota, E. W. Schaler, S. D. Wolf, C. Ballif, A. Cuevas, and A. Javey, "Efficient silicon solar cells with dopant-free asymmetric heterocontacts," Nature Energy, vol. 2, p. 15031, 2016.

[8] C. Battaglia, S. M. de Nicolas, S. De Wolf, X. Yin, M. Zheng, C. Ballif, and A. Javey, "Silicon heterojunction solar cell with passivated hole selective $\mathrm{MoO}_{x}$ contact," Appl. Phys. Lett., vol. 104, p. 113902, 2014.

[9] C. Battaglia, X. Yin, M. Zheng, I. D. Sharp, T. Chen, S. McDonnell, A. Azcatl, C. Carraro, B. Ma, R. Maboudian, R. M. Wallace, and A. Javey, "Hole selective $\operatorname{moo}_{x}$ contact for silicon solar cells," Nano Lett., vol. 14, pp. 967-971, 2014

[10] J. Geissbühler, J. Werner, S. Martin de Nicolas, L. Barraud, A. HesslerWyser, M. Despeisse, S. Nicolay, A. Tomasi, B. Niesen, S. De Wolf, and C. Ballif, "22.5\% efficient silicon heterojunction solar cell with molybdenum oxide hole collector," Appl. Phys. Lett., vol. 107, p. 081601, 2015.

[11] K.-U. Ritzau, M. Bivour, S. Schröer, H. Steinkemper, P. Reinecke, F. Wagner, and M. Hermle, "TCO work function related transport losses at the a-Si:H/TCO-contact in SHJ solar cells," Sol. En. Mat. Sol. Cells, vol. 131, pp. $9-13,2014$

[12] M. Bivour, J. Temmler, H. Steinkemper, and M. Hermle, "Molybdenum and tungsten oxide: High work function wide band gap contact materials for hole selective contacts of silicon solar cells," Sol. En. Mat. Sol. Cells, vol. 142 , pp. $34-41,2015$.

[13] L. G. Gerling, S. Mahato, A. Morales-Vilches, G. Masmitja, P. Ortega, C. Voz, R. Alcubilla, and J. Puigdollers, "Transition metal oxides as hole-selective contacts in silicon heterojunctions solar cells," Sol. En. Mat. Sol. Cells, vol. 145, pp. $109-115,2016$.

[14] M. Mews, L. Korte, and B. Rech, "Oxygen vacancies in tungsten oxide and their influence on tungsten oxide/silicon heterojunction solar cells," Sol. En. Mat. Sol. Cells, vol. 158, Part 1, pp. 77 - 83, 2016.

[15] J. Werner, J. Geissbhler, A. Dabirian, S. Nicolay, M. Morales-Masis, S. D. Wolf, B. Niesen, and C. Ballif, "Parasitic absorption reduction in metal oxide-based transparent electrodes: Application in perovskite solar cells," ACS Applied Materials \& Interfaces, vol. 8, pp. 17260-17267, 2016.

[16] L. G. Gerling, C. Voz, R. Alcubilla, and J. Puigdollers, "Origin of passivation in hole-selective transition metal oxides for crystalline silicon heterojunction solar cells," J.Mater. Res., vol. 32, pp. 260-268, 2017.

[17] M. Boccard, L. Ding, P. Koswatta, M. Bertoni, and Z. Holman, "Evaluation of metal oxides prepared by reactive sputtering as carrier-selective contacts for crystalline silicon solar cells," in IEEE 42nd PVSC, 2015.

[18] C. Granqvist, "Electrochromic tungsten oxide films: Review of progress 19931998," Sol. En. Mat. Sol. Cells, vol. 60, pp. 201 - 262, 2000.

[19] G. Oh, J. Jeon, K. S. Lee, and E. K. Kim, "Work function modification of tungsten-doped indium oxides deposited by the co-sputtering method," J. Nanosci. Nanotechnol., pp. 5109-5113, 2016.

[20] J. Kegel, H. Angermann, U. Stürzebecher, E. Conrad, M. Mews, L. Korte, and B. Stegemann, "Over 20\% conversion efficiency on silicon heterojunction solar cells by ipa-free substrate texturization," Appl. Surf. Sci., vol. 301, pp. $56-62,2014$.

[21] M. Mews, T. F. Schulze, N. Mingirulli, and L. Korte, "Hydrogen plasma treatments for passivation of amorphous-crystalline siliconheterojunctions on surfaces promoting epitaxy," Appl. Phys. Lett., vol. 102, p. 122106, 2013.

[22] F. Bussolotti, L. Lozzi, M. Passacantando, S. L. Rosa, S. Santucci, and L. Ottaviano, "Surface electronic properties of polycrystalline $\mathrm{WO}_{3}$ thin films: a study by core level and valence band photoemission," Surf. Sci., vol. 538 , no. 12 , pp. $113-123,2003$.

[23] J.-S. Lee, I.-H. Jang, and N.-G. Park, "Effects of oxidation state and crystallinity of tungsten oxide interlayer on photovoltaic property in bulk hetero-junction solar cell," J. Phys. Chem. C, vol. 116, pp. 13480 $13487,2012$.

[24] R. A. Sinton and A. Cuevas, "Contactless determination of currentvoltage characteristics and minority-carrier lifetimes in semiconductors from quasi-steady-state photoconductance data," Appl. Phys. Lett., vol. 69, pp. 2510-2512, 1996.

[25] M. Leilaeioun and Z. C. Holman, "Accuracy of expressions for the fill factor of a solar cell in terms of open-circuit voltage and ideality factor," J. Appl. Phys., vol. 120, no. 12, p. 123111, 2016.

[26] K. Heilig, "Determination of surface properties by means of large signal photovoltage pulses and the influence of trapping," Surf. Sci., vol. 44, pp. 421-37, 1974.

[27] Z. C. Holman, A. Descoeudres, L. Barraud, F. Z. Fernandez, J. P. Seif, S. De Wolf, and C. Ballif, "Current Losses at the Front of Silicon Heterojunction Solar Cells," IEEE J. Photovolt., vol. 2, pp. 7-15, 2012.
[28] D. Paluselli, B. Marsen, E. L. Miller, and R. E. Rocheleau, "Nitrogen doping of reactively sputtered tungsten oxide films," Electrochem. SolidState Lett., vol. 8, pp. G301-G303, 2005.

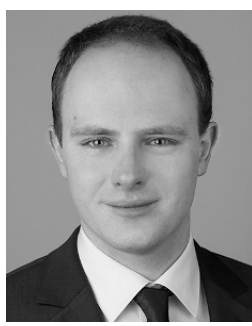

Mathias Mews has a B.Sc. and a M.Sc. in physics from the Freie Universität Berlin, Germany and received his $\mathrm{Ph} . \mathrm{D}$. from the faculty of electrical engineering and computer science of the TU Berlin. The work for his Ph.D. was conducted at the HelmholtzZentrum Berlin in the field of a-Si:H/c-Si solar cells. He is still working at the Institute for Silicon Photovoltaics at Helmholtz-Zentrum Berlin as a postdoctoral researcher and his research interests include in-system studies of electronic properties of semiconductor interfaces and selective contacts on silicon, especially transition metal oxide layers.

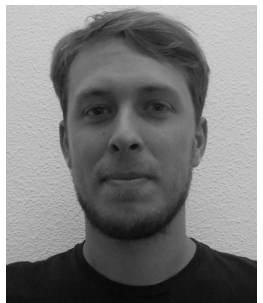

Antoine Lemaire was born 1993 in Orlans, France. In 2016, he conducted his master internship at the Institute for Silicon Photovoltaics of the HelmholtzZentrum Berlin, Germany. He received an Energy Masters degree in materials and solar processes from the University of Perpignan Via Domitia in Perpignan, France. He is currently doing his Ph.D in the CPV field at PROMES-CNRS laboratory in Perpignan, France. He is working on design optimization of multijunctions based on III/Sb materials through carrier lifetime measurement.

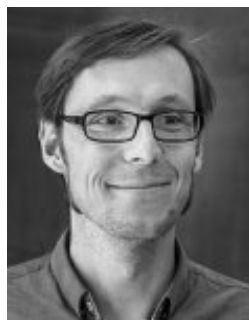

Lars Korte studied physics in Gottingen, Germany. He carried out his Ph.D. research with HahnMeitner-Institut Berlin, Berlin, Germany, and received the Ph.D. degree in physics from the University of Marburg, Marburg, Germany, in 2006. He joined the Laboratoire de Chimie Metallurgique des Terres Rares, CNRS, France, as a Visiting Researcher with a grant from the German Academic Exchange Service (DAAD). Since 2010, he has been the permanent staff member with HelmholtzZentrum Berlins (HZB), Berlin, Germany. He is currently the Group Leader for a-Si:H/c Si solar cells and advanced contact systems with HZB, Institute for Silicon Photovoltaics. His research interests include the electronic properties of thin films and heterointerfaces, high efficiency silicon heterojunction solar cells, and silicon-based tandem cells. 